\title{
Study on the Model of Entrepreneurial Talent Cultivation in Independent Colleges
}

\author{
He Hui \\ College of Technology, Hubei Engineering University \\ Xiaogan City,Hubei Province, China 432000
}

\begin{abstract}
Keywords: Talent cultivation model; Independent colleges; "Government-enterprise-college" collaborative cultivation

Abstract. Under the call of "nation-wide entrepreneurship, mass innovation", the cultivation of entrepreneurial talents is of important significance for the personality development of the students, the reform of higher education and even the development of the overall economy. This paper makes a comparison of the different modes of entrepreneurial talent cultivation in colleges and universities at home and abroad, points out the aspects worthy of learning and the shortages of them, and proposes a mode of entrepreneurial talent cultivation conforming to the independent colleges. It believes that the "government-enterprise-college" collaborative cultivation is the best model at present.
\end{abstract}

\section{Introduction}

In the general background of "nation-wide entrepreneurship, mass innovation", the cultivation of entrepreneurial talents by independent colleges has a special significance. It is conforming to the direction of national macro policy and is beneficial to seek new economic growth point; it is beneficial to improve the competitiveness of the independent colleges, making it develop soundly; it is also beneficial for the students in independent colleges to change their view of employment, promoting the high quality of employment.

Seeing from the national level. Nowadays, the economic growth allover the world is slowing down and China's domestic economy is facing further reform. The era of the era of knowledge-driven economy has much higher requirements on the talents. Traditional "informative" talents cannot meet the needs of economic development and the high quality talents with innovation and entrepreneurial ability become the new engine for economic growth. Thus it is in accordance with the development of society and the trend of the era to cultivate entrepreneurial talents.

Seeing from the college level. For colleges and universities, entrepreneurship education is equally important as academic education and vocational education. Colleges, whether research-based, teaching oriented, or vocational educational, all require conducting entrepreneurship education, which promotes the transformation from knowledge production to knowledge application. And as the independent colleges, their orientation of applied talents cultivation and the connotation of entrepreneurial talent cultivation coincide with each other. Therefore, it is of important value to explore a model of cultivating entrepreneurial talents based on the training of the ability of application for the survival and development of independent colleges.

Seeing from the student level. The cultivation of students' entrepreneurial ability can improve students' comprehensive quality, which on the one hand can make the students more competitive in the labor market and easier to obtain employment, on the other hand can also change students' view of employment and make them step on the path of self-employment under the employment pressure and realize a higher level of self development.

The comparative study of the models of cultivating entrepreneurial talents in colleges and universities at home and abroad

The models of cultivating entrepreneurial talents in foreign colleges and universities. Foreign universities have not specifically put forward the concept of entrepreneurial talents, but they lay emphasis on cultivating students' ability to solve practical problems in the whole higher education 
stage and penetrates naturally the entrepreneurial awareness in the process of the talent cultivation. The main modes of cultivating are in the following:

The comprehensive model in the United States

The United States is the birthplace of entrepreneurship education. It is the earliest that set related entrepreneurship courses at the Commercial College in Harvard University, conducting a comprehensive range of the entrepreneurial thinking and professional quality training to the students. The students receive professional education in school in the early stage of their education, and in the later stage they go to the corporation or community for entrepreneurship practice. Because of its systematicness and expertise, this kind of cultivation mode, also known as "focused mode", is the traditional education mode, and the business college or college of management is responsible for the daily management of teaching.

The mode which has been adopted by many colleges and universities in the United States is "magnet mode". It sets up the entrepreneurship education center in the colleges, opens courses in business or related towards all the students, taking in students with different major background and interests, providing students with a place for communication and cooperation, thinking collision, also responsible for project planning, operation and financing.

There are also a few colleges and universities adopting "radiation mode", in which the school establishes a coordinating committee of entrepreneurship education to be responsible for coordinating and guiding, and each college is responsible for the relevant faculty and program. The entrepreneurship education takes into consideration of the different needs of students in different majors, is integrated into the major courses, and emphasizes on the participation of the entire school teachers. This model emphasizes the information exchange and sharing between different students, and emphasizes the cooperation and communication between teachers.

The mentoring model in Germany. On the entrepreneurial talent cultivation, Germany mainly pursues the "mentoring" mode. This mode of cultivation requires establishing dedicated entrepreneurship training center, where teachers are mainly from technical experts in enterprises, and they teach and guide the students directly hand by hand, guiding them to start a business. First of all, students select projects according to their individual needs. Then, during the period of learning, teachers teach theories to the students, and the students also have a lot of opportunities to go to enterprises for internship to enhance their entrepreneurial skills. Students in learning, on the basis of theory and practice, complete the entrepreneurial plan for the project which they chose previously, and only when their plans are recognized by the entrepreneurship training center can they graduate. Finally, students may apply with the approved plan for bank loans or funds support for their entrepreneurship.

The embedded mode in Britain. In British universities, entrepreneurial talent cultivation has formed a kind of culture, penetrated into all aspects of school education. On one hand, the schools open entrepreneurship courses widely, through the general courses, elective courses, and even professional degree courses, to permeate into the school curriculum education; on the other hand, the schools also issue a series of service policy on entrepreneurship, giving all-round support for teachers' research on entrepreneurship education, students' initiation of entrepreneurship projects and entrepreneurial guarantee. In addition, British universities also maintain close ties with the enterprises, either the enterprise property rights owned by the school in whole or in part, or allowing companies to build laboratories in colleges and universities, providing students with a good entrepreneurial method and entrepreneurial resources.

The linkage model in Japan. In terms of the entrepreneurial talent cultivation in the Japanese universities, the objects of cultivation are not constrained by the campus students, and they also recruit society personnel who have the tendency to start a business; the mode of cultivation is not limited to the school and enterprise cooperation, and they will connect the government, social organizations, research institutions, intermediary service organizations, etc., to form a entrepreneurship service chain, to provide more information and technology to entrepreneurs and to provide entrepreneurship support all the way. For colleges and universities, they main undertake the 
entrepreneurship education, cultivate the students' entrepreneurial spirit and the professional quality and guide students' entrepreneurial planning; for the government, it can provide venture capital and policy support; for enterprises or other social organizations, they offer places for entrepreneurship.

From the above modes of entrepreneurial talent cultivation, we can see that colleges and universities should build entrepreneurial culture atmosphere, integrate the entrepreneurship education and the professional education, fully mobilize students' entrepreneurial zeal, and assemble a variety of factors to serve for students' entrepreneurship, such as combined with the enterprises, establishing platform for the students to practice and operation, striving for funds and policy support from all kinds of organizations and the government, and so on.

The models of cultivating entrepreneurial talents in domestic colleges and universities. The entrepreneurship education in China began late, marked by the first entrepreneurship plan competition held in Tsinghua University in 1998.In 2002, the Ministry of Education carried through entrepreneurship education trial in nine universities. After ten years of development, colleges and universities, according to their own situations and advantages, have actively explored and the entrepreneurial mode each has its own characteristics. Among them, several typical modes are the following:

The "double class" mode. This mode is represented by Renmin University of China, and it combined the first class and second class to carry out entrepreneurship education. Students on campus not only receive professional education, but also can take up entrepreneurship related courses as elective courses, participate in all kinds of entrepreneurship lectures, participate in the entrepreneurial plan competition, the marketing competition, etc.. Schools encourage students to actively participate in social practice and social public welfare activities, using their own knowledge to serve for the general public, at the same time of expanding the influence, their sense of responsibility increased, stimulating students' entrepreneurial thinking, and gradually forming the "entrepreneurial education" practical group based on the major, project and society as the organization form.

The market-oriented mode. This mode is represented by Beijing university of Aeronautics and Astronautics, and its characteristic is that it based on the market as the guidance and commercialized operation. Schools establish "entrepreneurship institution", professionally teaching students how to start a business, in order to improve the students' entrepreneurial knowledge and entrepreneurial skills; schools establish innovation park for college students, providing entrepreneurial place for students; schools also set up a venture fund, financing the "seed" stage of the entrepreneurial plan after their evaluation. This complete set of full tracking service, make the college students' entrepreneurship worry-free, greatly stimulating the students' entrepreneurial zeal.

The " enterprise-college- research" collaborative model. Colleges and universities implementing this mode are more. It adds more internship and practical training to the cultivation scheme of the students, pays attention to the joint training of the school and the enterprise, improving the students' entrepreneurial skills; it implements college students' scientific research plan, encouraging students themselves to make scientific research or involved in the teachers' scientific research work, in order to cultivate students' innovative spirit. At the same time, it encourages teachers to participate in the production practice in enterprises, integrating the market knowledge into the classroom, so as to optimize the classroom teaching and scientific research, and increase the epochal character and the applicability of knowledge.

From the above, you can see that the entrepreneurship education in our country has developed from drawing lessons from other countries' experience to stage to the direction of localization. Though there is a lack of systematic research, all the colleges and universities has accumulated some experience in entrepreneurial talent cultivation. 
A comparison between the models of cultivating entrepreneurial talents in colleges and universities at home and abroad.

\begin{tabular}{|c|c|c|c|}
\hline Item & $\begin{array}{l}\text { Contents of } \\
\text { comparison }\end{array}$ & In the foreign countries & In China \\
\hline \multirow{7}{*}{$\begin{array}{l}\text { The education } \\
\text { modes of } \\
\text { entrepreneuria } \\
\text { l talents }\end{array}$} & $\begin{array}{c}\text { Educational } \\
\text { body }\end{array}$ & $\begin{array}{l}\text { Business College, or Business } \\
\text { Administration College as the main } \\
\text { body, setting full-time } \\
\text { entrepreneurship guidance teacher }\end{array}$ & $\begin{array}{l}\text { Starting in comprehensive } \\
\text { universities and engineering } \\
\text { colleges, relevant professional } \\
\text { teachers take part-time } \\
\text { entrepreneurship guidance } \\
\text { curriculum }\end{array}$ \\
\hline & Teaching object & $\begin{array}{l}\text { To take the exam admission system } \\
\text { to determine enrollment, cultivating } \\
\text { entrepreneurial talents directionally }\end{array}$ & $\begin{array}{l}\text { Directed by personal interest of } \\
\text { college students, voluntary } \\
\text { participation }\end{array}$ \\
\hline & education mode & $\begin{array}{l}\text { Teaching on and off campus, } \\
\text { integrating many resources as the } \\
\text { society, college and enterprise to } \\
\text { serve for cultivating entrepreneurial } \\
\text { talents }\end{array}$ & $\begin{array}{l}\text { Carrying on Class and teachers as } \\
\text { the center of gravity, the } \\
\text { theoretical study and practice in } \\
\text { the process of talent cultivation }\end{array}$ \\
\hline & $\begin{array}{l}\text { Teaching } \\
\text { contents }\end{array}$ & $\begin{array}{l}\text { Entrepreneurial knowledge and } \\
\text { entrepreneurial approach, } \\
\text { innovative thinking and ability }\end{array}$ & $\begin{array}{l}\text { Entrepreneurial policy, } \\
\text { entrepreneurial ideas, } \\
\text { entrepreneurial direction and } \\
\text { entrepreneurial approach }\end{array}$ \\
\hline & $\begin{array}{l}\text { Teaching } \\
\text { methods }\end{array}$ & $\begin{array}{l}\text { Teaching, guided practice and } \\
\text { simulated business independently, } \\
\text { cultivating students' divergent } \\
\text { thinking }\end{array}$ & $\begin{array}{l}\text { Classroom teaching, special } \\
\text { seminar and enterprise practice, } \\
\text { emphasizing polymerized thinking }\end{array}$ \\
\hline & $\begin{array}{c}\text { Support for } \\
\text { entrepreneurshi } \\
\text { p }\end{array}$ & $\begin{array}{l}\text { The government not to participate in } \\
\text { social entrepreneurship and its basic } \\
\text { operation, relying on } \\
\text { entrepreneurial project financing }\end{array}$ & $\begin{array}{l}\text { Declare and audit, Offering certain } \\
\text { policy and financial support after } \\
\text { declaration and audit }\end{array}$ \\
\hline & $\begin{array}{c}\text { Development } \\
\text { tendency }\end{array}$ & $\begin{array}{l}\text { More interdisciplinary technology } \\
\text { entrepreneurship and } \\
\text { interdisciplinary cooperated } \\
\text { entrepreneurship }\end{array}$ & $\begin{array}{l}\text { Promoting economic structural } \\
\text { adjustment, to realize the } \\
\text { entrepreneurial innovation of all } \\
\text { the people }\end{array}$ \\
\hline
\end{tabular}

It can be found that entrepreneurship education is still in the exploratory stage in China, and need to be reformed from several aspects.

First, to strive to cultivate the students' innovative entrepreneurial spirit. Thought control action. If students have no business idea, cultivation is impossible.Therefore, the universities should attach importance to the cultivation of the students in the ideological education, transmit entrepreneurial ideas to the students and creat an atmosphere.

Second, to promote teaching reform with entrepreneurial employment as the guidance.In talent cultivation scheme, increase the weight of practice teaching, and reduce the onerous theoretical teaching, also theoretical teaching should be able to guide practice.Pay attention to the diversity of practice teaching, encourage students to participate in social survey, corporate training, etc., to highlight the cultivation of student's innovation ability and entrepreneurial quality.

Third, to integrate all resources to serve for students' entrepreneurship.Currently the entrepreneurial talent cultivation in colleges and universities is mainly based on school, but the teaching, scientific research and financial strength is uneven in different schools, leading to obvious quality difference of talent cultivation and small quantity of actual completion of startup projects. Therefore, we should speed up the integration of available resources as the society, school, and enterprise to cultivate entrepreneurial talents and realize a complete system for personnel selection, training and output. 


\section{The model of cultivating entrepreneurial talents in independent colleges}

The independent colleges were started in 2001 and they took private capital as the principle source of capital. After ten years of development, they are now facing a transformation. Unlike research universities, independent colleges mainly train applied talents for the local economy. Therefore, the path of combining "government-enterprise-college", which starts from the needs of local industry development, actively cooperates with enterprises, and strives for a series of policy support, is an effective way of cultivating entrepreneurial talents for independent colleges. It is stated in specifications as follows:

The Government: to guide and guarantee.Government is not only the manager of the higher education, but also the policy makers and supporters of the economic environment. In the early days when the interests of all parties are not yet clear, the government can lead school and enterprise to cooperate, stipulate cooperation system with clear rights and liabilities, lower transaction costs, on one hand to support the development of higher education, on the other hand to promote the reform and development of the industry. The government can also integrate a range of resources to support entrepreneurial talent cultivation. For example, it can set up special funds, guide private investment and set up private donations to support innovation project funding; it can establish college students' science and technology park, entrepreneurial innovation demonstration base, to provide a forum for entrepreneurial projects; it can give the entrepreneurial projects of college students privileges and priorities in terms of the registered capital, taxes, government procurement, etc.. In short, the government plays the role of chief designer in prompting school and enterprise cooperation and the integration of resources.

The enterprises: to integrate and support. The enterprises, as the demand side of talents and the active individual in the market, can be fully involved in the formulation of the school's entrepreneurial talent entrepreneurship scheme, putting forward their own opinions for the courses, teachers, target students, teaching methods and so on; they can send enterprise management staff to study in the school, also can encourage school teachers to walk into the enterprise, to exchange mutually and search for the conjunction point of theory and practice; They can and build labs with colleges and universities jointly, to give timely feedback to colleges and universities the demand of the market, and to make scientific research achievements into productivity as soon as possible; they can give students a platform to operate and practice their courses, making students able to do in learn and to learn in do, promoting their entrepreneurship quality comprehensively; they can also give students' excellent entrepreneurial projects the "first pot of gold", not only to promote the enterprise's image, but also to widen the channel of the enterprise's income.

The colleges: to educate and dominate. Talent cultivation cannot be separated from the colleges, which are specifically places to educate people, so the status of colleges is decisive. On the cultivation of entrepreneurial talents, the colleges are in a core position and are also pioneers. Colleges need to develop a complete cultivation theme, to mobilize all resources to serve for talent cultivation, to build a reasonable evaluation system, in order to ensure the quality of entrepreneurial talent cultivation.

Colleges should create an atmosphere of entrepreneurial culture. They can set up public elective courses related to entrepreneurship, regularly invite entrepreneurs and entrepreneurship students to give lectures, establish entrepreneurial BBS, hold entrepreneurship plan competition, to create full-bodied atmosphere of entrepreneurial culture and stimulate students' entrepreneurial zeal.

Colleges should set up a center for entrepreneurship to deal with everything related to entrepreneurship affairs, including the selection of students and teachers, the formulation of the entrepreneurship scheme, the financing of the entrepreneurship project, etc.

Colleges should have a stable team of high-quality teachers, mainly to teach students knowledge of professional skills needed in entrepreneurship. They should open courses such as innovative thinking and decision-making tools, team building and management, business opportunity recognition and evaluation, venture investment and risk management, business model, marketing of new ventures and project implementation. 
Colleges should have strict knockout system, to ensure the quality of talent cultivation and the completion of the entrepreneurship projects. In the early stage, the college can take the way of registration to enrol students with entrepreneurial enthusiasm to participate in courses, and issue the certificate for students obtaining all qualified grades; in the middle stage, the college organizes students in entrepreneurship class to participate in internal and external entrepreneurship plan contest, organize relevant personnel selected from colleges and enterprises to assess and select the projects that have market potential, and give material reward and credits reward; in the later stage, the college select a certain percentage of the items from the winning projects for entity incubation, besides the college's special supporting fund for entrepreneurship and one-on-one equipped mentors, also striving for the full support of the government and enterprises to promote the successful landing of entrepreneurship projects.

In short, the "government-enterprise-college" collaboration should be the best model of the entrepreneurial talent cultivation in the independent colleges at present, where the government is mainly responsible for the upper policies to guide and guarantee, the college is responsible for the education of theoretical knowledge, the enterprise closely cooperate with the school, to provide practical support, the government, enterprise, school each performs its own functions and integrates with one another, jointly develop the students' spirit and ability of entrepreneurship and create entrepreneurial talents.

\section{References}

[1]. Xu Jianjun, Xu Yan-chao, Yan, Li-me,et.al. Research on the method of optimal PMU placement. International Journal of Online Engineering,v9, S7, p24-29, 2013

[2]. Xu Jian-Jun, Y. Y. Zi., Numerical Modeling for Enhancement of Oil Recovery via Direct Current. International Journal of Applied Mathematics and Statistics，2013，43（13） : 318-326

[3]. Longchao, Zhu Jianjun, Xu; Limei, Yan. Research on congestion elimination method of circuit overload and transmission congestion in the internet of things. Multimedia Tools and Applications, $\mathrm{p}$ 1-20, June 27, 2016

[4]. Yan Limei, Zhu Yusong, Xu Jianjun,et.al. Transmission Lines Modeling Method Based on Fractional Order Calculus Theory. TRANSACTIONS OF CHINA ELECTROTECHNICAL SOCIETY, 2014 ,Vol.29,No. 9:260-268 (In Chinese)

[5]. YAN Li-mei, CUI Jia, XU Jian-jun,et.al. Power system state estimation of quadrature Kalman filter based on PMU/SCADA measurements. Electric Machines and Control. 2014, Vol.18 No.6,: 78-84. (In Chinese) 